\title{
Influence Factors Venture Capital, Farmer's Institutions and Bussiness Typed to Farmer's Successfull of the Independently Direct Aid Program in Ogan Ilir
}

\author{
Tien Yustini ${ }^{1}$ \\ ${ }^{1}$ Management Department of STIM AMKOP Palembang, Indonesia \\ Correspondence: Priyono, Post Graduate Management Program, Universitas Bina Darma, Palembang, Indonesia. \\ E-mail: priyono.unu_sidoarjo@yahoo.com
}

Received: April 23, 2017

doi:10.5539/ijbm.v12n7p174
Accepted: May 23, 2017

Online Published: June 7, 2017

URL: https://doi.org/10.5539/ijbm.v12n7p174

\begin{abstract}
This research aimed to analized the Capital from Independently program, Farmer's Institutions and Bussiness typed to Farmer's Successfull of the Independently Direct Aid Program (BLM) in Ogan Ilir. In this research are farmers who's given the revolving fund from independetnly Direct Aid Program about 111 farmers. But in this research just 80 farmers whose being a sample. Sampling method that used in this research is purpossive sampling, which the farmers given revolving fund from BLM. Used the SPSS 22 Version, getting conclusion as; Capital Factors that taste of BLM, Business typed and Farmer's institutions significant effect on the success of the implementation of the BLM program in Ogan Ilir seen with the revolving fund, where there are $41 \%$ of those who carry out rolling the BLM program funds more than five (5) times. Statistical analysis showed that the independent variables have a strong relationship to the dependent variable, where the value of the coefficient of determination (Adjusted $\mathrm{R}^{2}$ ) of 0.762 . The Revenue Percentage Improvement BLM amounted to 0.828 against the percentage increase farmers' income that means the model can explain the variance of data $76.2 \%$ of the success of the BLM Program. Simultaneously (F-test) Capital variable, Business Type, Farmers Institutions real and significant effect on the success of the BLM program. The results of the $t$ test (partially) Type of Business has a positive and significant impact on the success of the BLM program. While the variable capital, and the Farmer's Institution, a significant negative effect on KBBLM Program.
\end{abstract}

Keyword: bussiness typed, direct aid fund program, revolving; rural, venture capital

\section{Introduction}

Rural in Indonesia still has a lot of potential that can be developed, so that the welfare of people in rural areas can be improved. That's why they did not interest in droves to go to town (migration) only to become unskilled laborers or work in the informal sector are in fact not able to improve the welfare of the community. The government continues to undertake various programs in rural areas, of course, efforts to develop rural development must be grown through a process of empowerment of rural communities. Thus the expected level of community participation grow from the bottom as initiative and creation born of a sense of awareness and responsibility. The essence of rural development in principle be done by, of, and for people with direction, guidance, coaching, support, and supervision of the government.

Law No. 25 of 2004 on National Development Planning System later became an umbrella for the implementation of development that provides a space for people as the subject of development. The law emphasizes that one of the goals of development is to increase community participation. However, even though the product has been included in the legislation, an effort to foster community participation has got a strong enough challenge of planning model that uses a technocratic approach and politics. The existence of public interests, technocrats, and politics we should find the right meeting point for the best solution in developing rural development in Indonesia.

Rural development will be focused on the activities of the villagers, and is expected to provide a broad multiplier effect, such as the expansion of employment, investment, infrastructure development. In addition, the expected occurrence of backward linkages and forward both between villages and between the villages with the town. Further expected improvements in the quality of life and prosperity for the people of the village and at the same time being able to overcome poverty in the village 
Despite the potential of the countryside in South Sumatra is still very large, but in fact until now most farmers are still many whose are categorized as poor. The fundamental problem faced by farmers is the lack of access to sources of capital, markets, technology and peasant organizations are still weak. Moreover in general, most farmers in Indonesia is a farmer who owns the narrow land and less optimal. So are with farmers in Ogan Ilir South Sumatra

According to Todaro (2000: 21) argues that the core of the development is the adequacy (sustenance) is the ability to meet basic needs, selfish is to be fully human, freedom of attitudes hamper the ability to choose. The complexity problems community and government by Rondinelli (1990: 54), decision making centralized inefficient, expensive and difficult to implement, therefore, now how the (local) government is able to organize and provide a wide range of public services, decentralization, democracy and empowerment made the election to eliminate the short comings of a centralized government. In Indonesia, the efforts made by the enactment of Law No. 22 of 1999 which provides a tremendous opportunity for districts to develop and cultivate growth in the region as the home base.

Efforts to develop rural development must be grown through a process of empowerment of rural communities, thus the level of community participation that grows from the bottom as initiative and creation, born of a sense of awareness and responsibility of society is an absolute requirement. In this case, the essence of rural development in principle be done by, of, and for people with direction, guidance, coaching, mentoring, assistance, and supervision of the government. Therefore, it is natural when rural development should be a top priority in all strategic planning and policy development in Indonesia.

In 2006, the government has formulated an integrated poverty reduction on the basis of community empowerment. The program is the National Program for Community Empowerment (PNPM). PNPM is poverty reduction efforts involving elements of society, from the planning stage, action to monitoring and evaluation. In order to address and solve the problems of poverty, the government set a medium of term development plan that focuses on rural agricultural development. One of them reached through agri-business approach and strengthening agricultural institutions in rural areas. (Regulation of the Minister of Agriculture, 2008). This program is the Rural Agribusiness Development (PUAP), the form of direct grants independently as capital gains to farmers through Combined Farmers Group. Farmers are expected to utilize and roll the funds to develop agribusiness in order to increasing income of the farmers so they able to out of poverty. This program has been implemented by the Ministry of Agriculture of the Republic of Indonesia since 2008 until. 2013, as well as in South Sumatra

Some of the factors that determine the success of poverty alleviation programs are: a). Awareness of local values; b). Integrated and comprehensive approach; c). Human Resource Development; d). Institutional role; e). Commitment of the community to come forward; f). Their formidable movers figures and role models, g) Mind set the public about the direct aid program.

In the district of Ogan Ilir acceptance of Direct Assistance funds independently from the 2008 - 2013 in 14 Districts with the Combined farmers Group numbers as 111 (Source: Agency for the Assessment of Food Crops, processed data 2015). Issues to be discussed are the most dominant factors that determines the success of the program help alleviate poverty through districts Direct Independent in Ogan Ilir, South Sumatra. Credit Program / revolving fund for small businesses as one of the region's economic development efforts will not succeed without the immaterial aspects such as freedom from dependence. Empowering certainly lending programs / revolving fund for the community. Community involvement in planning, determining the selection and implementation of the program will foster community empowerment. According to Ledgerwood $(1999$, p. 1) defines microfinance as the provision of financial services to low-income society, including small traders, street vendors, small farmers, sellers of services (hairdresser, rickshaw), artisans and small producers.

From the description above that the study is interested in studying how the implementation of the program credit / revolving fund for small businesses in the poverty alleviation efforts. Program of revolving funds are Ogan Ilir regency government policies in order to improve the standard of living, society, creating empowerment of the poor / poor farmers. The success of poverty reduction be marked with the poor whose being prosperous and self-reliant through the creation of employment opportunities increase revenue on an ongoing basis. The success of economic development must be supported by planning and implementation in other fields. Economic development policies intended to enhance prosperity in the sense of the greatest possible extent, economic development activities are always seen as part of the overall development effort run by a society. Economic development includes only the business community to develop economic activity and enhancing the level of people's income, while the overall development efforts include the development efforts of social, political, and cultural. 


\section{Methods}

Currently agribusiness increasingly strategic position, is expected to increase the income of farmers, agribusiness also expected to embrace the farmers to get involved in it, and can feel the increased in added value . During this agribusiness has indeed been progressing quite rapidly, but the added value was not enjoyed by most farmers. The reality is the "farmers tie" better enjoy it. However, in an effort to develop agribusiness, farmers are still spearhead. The nation revival of Indonesia can not be separated from the rise of agriculture and farmers. With the application of the concept of agribusiness, the expected acceleration of agricultural development and independence of the nation.

Developing agribusiness required huge capital support, in this case the bank has not been a lot of capable business association with the agribusiness sector, it is mainly due to the high risk factor, particularly in farming activities. Cultivation of crops, livestock and fish is influence environment, both macro and micro. Moreover, it is still expected on offense agribusiness marketing should always pay attention to international quality standards. Often it happens when agribusiness products exported be returned because of inadequate quality.

Conceptually, community empowerment is an effort to improve the dignity of society is in a state of not being able to escape the trap of poverty and under development. In other words, is to enable and empower the community's independence. According to Pranarka and Prijono (1996), man is the subject of itself, emphasizing the empowerment process in providing the ability for people to be empowered, encourage or motivate the individual to have the ability or the empowerment to determine the choice of his life. According to Sumarjo (2010) effective community empowerment makes people become useful, the society becomes more dynamic, more adaptive to changes in the environment, better able to access appropriate technologies, extensive knowledge, cosmopolitan, and empathy for outsiders. The change from the traditional social system occurs through a process of awareness and participation.

This research was conducted in Ogan Ilir South Sumatra, with the consideration that the district received funds Mandiri Direct Aid almost every year from the beginning of the program in 2008 until 2013. The villages surveyed prelude to seek comparisons are recipients of direct assistance Mandiri in 2009 and 2010, since in 2009 and 2010 programs are much better and there are already coordinating self extension in this case the extension of districts for Direct Aid Mandiri called Supervisor Mitra Farmer and village extension workers are freelance extension. While the data for this study were drawn recipient data independently Direct Aid in 2009.

The population is all self-contained direct beneficiaries from 2008 until 2013, which amounted to 200 people. The samples in this study using a formula Slovin (Sevilla et.al, 1993), because the population is more than 100, the looseness of accuracy can be taken 5-10\% (Riduwan and Kuncoro, 2008). By using the formula slovin then the sample is determined as much: 80 people are calculated as follows:

$$
\mathrm{n}=\mathrm{N} / 1+\mathrm{Ne}^{2}
$$

Where:

n: number of samples

$\mathrm{N}$ : the number of population

e: fault tolerance limit (error tolerance)

The sample used by 80 farmers recipient Direct Relief Fund Mandiri. Techniques used in the sampling that is technically non-probability samples are purposive sampling method. According to Ferdinand (2006) purposive sampling is a sampling of the population based on certain criteria where the population of farmers grouped in a homogenous group that rice farmers and rubber farmer beneficiaries been PUAP in 2009, and of the entire population is drawn samples from each of these groups.

The data used in this research is the primary data and secondary data. Primary data was taken from respondents sourced from rice farmers and rubber farmers direct beneficiaries independently. Data was collected through interviews based on a questionnaire that was designed specifically for this study. In addition to primary data, secondary data was also collected to support the research. Secondary data were obtained through a search of documents, reports of previous studies and observations in the field and literature who helped in the research literature.The research variables consisted of: Institutional (X1); Type of Business (X2); Capital from Direct Aid Mandiri (X3); While the variable Y is the successfull variable that measured by the level of income. These variables are defined as follows: 
Table 1. Operational definitions

\begin{tabular}{lll}
\hline Variable & Definitions & Category Measurement \\
\hline Institutional (X1) & $\begin{array}{l}\text { Institutions involved in the implementation of } \\
\text { the BLM. }\end{array}$ & - Farmers (Poktan) \\
& & - Farmers Group (Gapoktan) \\
& & - LKMA \\
Type of Business & The work done by farmers using BLM & - Livestock (L) \\
(X2) & & - Plantation (P) \\
& & - Crop (C) \\
& & - Horticulture (H) \\
& & - Off Farm (OF) \\
Capital BLM (X3) & Capital originating from the BLM (first take) & $-\quad$ Rupiahs \\
The success (Y) & & The percentage increase in income received by farmers compared to \\
& & the Top Income \\
\hline
\end{tabular}

\section{Result and Discussion}

The total area of Ogan Ilir regency is 2,666,07 $\mathrm{km}^{2}$ consisting of $65 \%$ of land and $35 \%$ swamp. North side adjacent to the city of Palembang and Banyuasin district, next to the South with the district Ulu Ogan, Ogan Ilir, the west with the district of Muara Enim and Prabumulih and the east with the district Ogan Komering Ulu, Ogan Ilir and East of OKU . Ogan Ilir District consists of 16 districts, 14 villages and 227 villages. Based on data from 2014 population of 397.439 inhabitants. OI district population consists of ethnic Ogan, Gotu kola, Penesak and immigrants who generally came from the Javanese and Sundanese.

Direct Aid Program Mandiri, which started since 2008 up to 2013 has been rolled out in most of the villages in Indonesia as well as villages in South Sumatra. Through farmers' groups combined, every village received help 100 million that should have been distributed to members of farmers based on the Proposed Plan Members (RUA) and the Proposed Plan Group (RUK) and its rolling. Reality on the ground aid is widely distributed with no proposals planned, or loaned to a member of such borrowing in the cooperative, only if the loan at the cooperative, borrowers feel obliged to return while lenders Direct Aid Mandiri, which in this case are members of farmer groups most feel that the funds PUAP a grant from the government so it does not feel obliged to repay, in other words that the funds are rolled tends unproductive.

In interviews with the members of farmers in villages that received funds Mandiri Direct Aid, formation of farmer groups in the villages just for the sake of obtaining funds aid program Mandiri is not formed naturally.

Interviewed on a preliminary survey in villages that got the BLM, most of these programs fail to achieve the goals and objectives of the BLM program. This is because the process of planning and decision making in development programs often done using a top-down approach, technocrats and political. System should be developed with a participatory or bottom up by placing the community as the main party or the center of the development. Such an approach is more empowering communities, namely model 'Empowerment' (PM). The basic process of community empowerment is the experience and knowledge about the existence of a very extensive and useful as well as their willingness to get better. This process is the starting point for the community's independence in order to improve their living standards, usage and access local resources as possible, both natural resources and human resources. In this case the community must have local knowledge.

Based on observations and interviews in the field, in fact only a few villages receiver BLM successfully meet the BLM coaching process stages, namely in the first year and second year of the utilization of funds the establishment of savings and loan business unit. Most of the villages are given help is not on target, whereas in the third year, independent direct assistance from BLM program should be used as the strengthening of capital or initial funding for the growth of Microfinance Institutions (MFI-A) on Gapoktan. BLM program implemented by the farmers (owners of the funds or tenants), farm labor, product processing and marketing of agricultural products, especially for poor families in the villages / wards, through gapoktan as an institution that is owned and managed by farmers.

The allocation of funds from the BLM program has been set by the government for food crops, horticulture, plantation, farm and off-farm activities (outside the farm but have no relation to agriculture). Based on the reporting system created by the related department with reality based on surveys and interviews on the ground in the villages who received BLM is not a research site is in sharp contrast, the average farmer does not understand those funds are allocated. It is caused by many factors, among others: assistance and guidance to members of the 
user group union BLM funds are lacking, before the program is implemented. So most farmers are not clear and do not understand the BLM program especially benefit.

Result of interviews with residents whose received BLM in village communities rubber farmers, they use the BLM to open new lands rubber plantations because at the time of BLM rolled, rubber prices are quite high, whereas based on the loan amount on average to be accepted by the members poktan / gapoktan, BLM must be used only enough to maintain the rubber plantation that was so. New land opening rubber plantation will cost about five (5) million plus maintenance until it is time to produce within a period of approximately 8 years. As known division of BLM funds for a village of only 100 million, on average per village there are five (5) farmer groups with a total membership of 20 farmers each.

So should funds be divided equally, per farmer group members each only get 1 million rupiahs. The funds are only sufficient for maintenance for rubber farmers, or if made for the planting horticultural farming and making small business (off farm) are most likely to do. Lending mechanisms should be through the proposed member (RUA) or farmer groups RUK) then it should be returned, one way of return do is refund within 11 months. Once paid, the member can borrow again, but many people are not returning, this is what causes of failed the BLM program , namely the lack of public awareness in terms of return grants BLM. Based on the borrowing and repayment of BLM for 4 (four) times, there are as many as $41 \%$ (33 of 80 respondents) which can also quite good Figure 1 . The role of the farmer (poktan / gapoktan) and financial institutions are in accordance with the purpose of BLM . Long duration of members have joined the group as much as $85.71 \%$ of farmers have joined for 7 to 8 years at the time of primary data collection in the field, mean that members are already accustomed to working group and has a working group focused enough.

If examined in terms of the amount of capital BLM distributed at the beginning of the division, it means the same as described above that the amount is sufficient to finance businesses that have been selected and the selection of the type of business is appropriate because respondents who used it were able to use these funds and rolling up to four times number of initial funding BLM same that between 1-2 million, but there is a lend up to 5 million, but the effort failed. Although it is not smooth, the loan fund stretcher can still be restored and could for the next year but the amount is decreased. As explained above, the success of the farmers is capable of rolling BLM well also influenced by selection of the type of business where the business chose Horticulture (40.48\%), Off Farm (23.81\%), Rice (19.05\%), followed by, Ranch (14.29\%) and Oil (0.24,\%). workgroups quite purposeful.

Selection of the right type of business if the terms of the land area is managed, where as many as $66.67 \%$ of respondents have / working area of 0.5 ha, as much as $30.95 \%$ manage 1 ha of land. Based on the selection of the selection of the type of business and off farm horticulture business is more dominant in adapting to the environment, people acquire and develop a wisdom that intangible knowledge, ideas, customary norms, cultural values, activities, and equipment as a result of abstraction of environmental management.

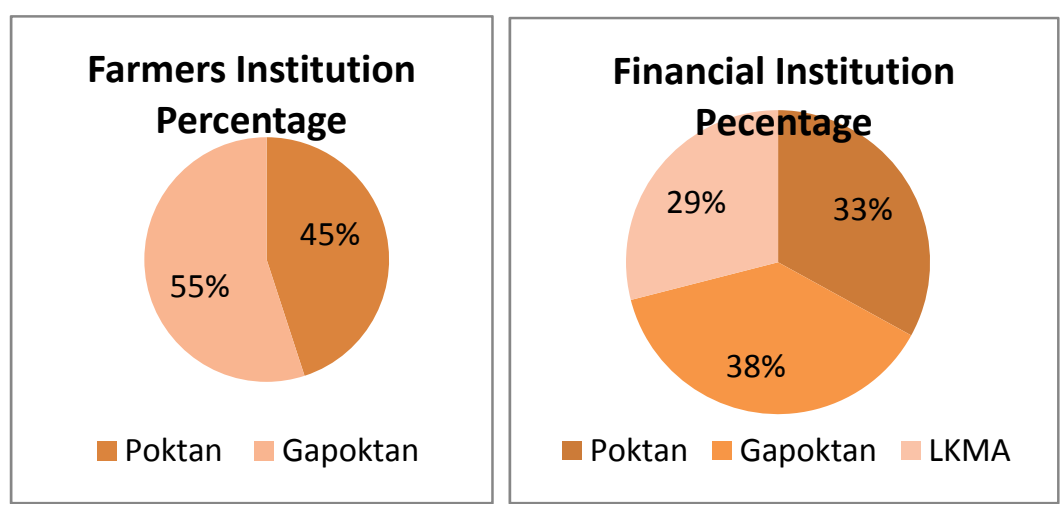

Figure 1. Overview institutional factor respondents BLM Loan Fund

Results of Hypothesis Testing with Multiple Linear Regression Analysis of the Independent Variables Dependent Variables are shown in the following table: 
Table 2. Summary model dependent variable linear regression towards KBBLM

\begin{tabular}{lllll}
\hline Model & $\mathrm{R}$ & $\mathrm{R}^{2}$ & Adjusted $\mathrm{R}^{2}$ & Std. Error of the Estimate \\
\hline 1 & 0.886 & 0.785 & 0.762 & 0.40003 \\
\hline
\end{tabular}

a. Predictors: (Constant), Capital of BLM (X1), Type of business (X2), Farmer Oganization ( $\left.\mathrm{X}_{3}\right)$.

b. Dependent Variable: KBBLM

Based on Table 2. multiple correlation values obtained at 0.886 , these values indicate a close positive relationship between the variables of Capital BLM (X1), Type of Business (X2), the Peasant Organization (X3) on dependent variable is the percentage of Income derived from the Fund assistance The value BLM coefficient of determination (Adjusted R2) of 0.762 . This shows that the model can explain the variance data that is $76.2 \%$ against KBBLM. While the rest influenced by other factors.

Table 3. Summary Multiple linear regression model independent variables to success program BLM

\begin{tabular}{lllll}
\hline Model & $\mathrm{R}$ & R Square & Adjusted R Square & Std. Error of the Estimate \\
\hline 1 & $0.919^{\mathrm{a}}$ & 0.844 & 0.828 & 0.06721 \\
\hline
\end{tabular}

a. Predictors: (Constant), Capital of BLM (X1), Type of business (X2), Farmer Organization ( $\mathrm{X}_{3}$

b. Dependent Variable: KBPLM.

Table 3. shown as the multiple correlation values obtained at 0.919 , these values indicate a close positive relationship between the independent variable capital BLM (X1), Type of Business (X2), Farmers Organization (X3), the dependent variable is the percentage of additional revenues from Direct aid Independent and dependent variable. The value of the coefficient of determination (Adjusted $\mathrm{R}^{2}$ ) of 0.828 . This shows that the model can explain the data variance of $84.4, \%$. While the rest influenced by other factors

Based on Table 4 is a value or a value Fcount 34,502 pvalue 0,000 , for a value pvalue $<\alpha$, then Ho is rejected. That is, the real level of $5 \%$ be declared no positive and significant influence between the variables

Table 4. Summary of Linier Regression of independent Variable to KBBLM Success

\begin{tabular}{lllllll}
\hline Model & & Sum of Squares & Df & Mean Square & F & Sig. \\
\hline 1 & Regression & 4.404 & 19 & 0.232 & 51.316 & $.000^{\mathrm{b}}$ \\
& Residual & 0.813 & 61 & 0.005 & & \\
& Total & 5.217 & 80 & & & \\
\hline
\end{tabular}

a. Predictors: (Constant), Capital of BLM (X1), Type of business (X2), Farmer Organization $\left(\mathrm{X}_{3}\right)$.

b. Dependent Variable: KBPLM.

Table 5. Table Anova and Testing Results Institutional Factors against KBBLM

\begin{tabular}{lllllll}
\hline Model & & Sum of Squares & df & Mean Square & F & Sig. \\
\hline 1 & Regression & 104.902 & 19 & 5.521 & 34.502 & 0.000 \\
& Residual & 28.804 & 61 & 0.160 & & \\
& Total & 133.706 & 80 & & & \\
\hline
\end{tabular}

a. Predictors: (Constant), Capital of BLM (X1), Type of business (X2), Farmer Organization $\left(\mathrm{X}_{3}\right)$.

b. Dependent Variable: KBPLM.

Capital of BLM (X1), Type of Business (X2), the Peasant Organization (X3), the dependent variable is the percentage of Income from BLM. This shows that pursuant to Test F, there is simultaneously a positive and significant influence bet 
Table 6. Anova table and testing results of independently variable to KBBLM

\begin{tabular}{lllllll}
\hline Model & & Sum of Squares & Df & Mean Square & F & Sig. \\
\hline 1 & Regression & 4.404 & 19 & 0.232 & 51.316 & $.000^{\mathrm{b}}$ \\
& Residual & 0.813 & 61 & 0.005 & & \\
& Total & 5.217 & 80 & & & \\
\hline
\end{tabular}

a. Predictors: (Constant), Capital of BLM (X1), Type of business (X2), Farmer Organization ( $\mathrm{X}_{3}$ ).

b. Dependent Variable: KBPLM.

Based on Table 6 . The obtaine value pvalue 0,000 Fcount 51.316 or value, because the value pvalue $<\alpha$, then Ho is rejected. That is, the real level of $5 \%$ be declared no positive and significant influence of independent variables on the dependent variables. This shows that pursuant to Test F, there is simultaneously a positive and significant influence between the independent variable capital of BLM (X1), Type of Business (X2), the Peasant Organization (X3), the dependent variable is success of BLM through increasing revenue.

Table 7. Regression Coefficients Values and Testing Results Independent Variables to KBBLM

\begin{tabular}{|c|c|c|c|c|c|}
\hline \multirow[b]{2}{*}{ Model } & \multicolumn{2}{|c|}{$\begin{array}{l}\text { Unstandardized } \\
\text { Coefficients }\end{array}$} & \multirow{2}{*}{$\begin{array}{l}\text { Standardized } \\
\text { Coefficients } \\
\text { Beta }\end{array}$} & \multirow[b]{2}{*}{$\mathrm{t}$} & \multirow[b]{2}{*}{ Sig. } \\
\hline & $\mathrm{B}$ & Std. Error & & & \\
\hline (Constant) & 0.669 & 0.411 & & 1.626 & 0.106 \\
\hline X1 Capital of BLM (M) & 0.040 & 0.051 & 0.034 & 0.789 & 0.431 \\
\hline \multicolumn{6}{|l|}{ X2 Type of Business (JU) } \\
\hline Plantation $(\mathrm{Pk})$ & 0.263 & 0.168 & 0.099 & 1.569 & 0.118 \\
\hline Crops (TP) & -0.517 & 0.210 & -0.290 & -2.462 & 0.015 \\
\hline Horticulture (H) & 0.483 & 0.148 & 0.268 & 3.261 & 0.001 \\
\hline Off Farm (OF) & 0.925 & 0.232 & 0.434 & 3.983 & 0.000 \\
\hline X3 Farmer Organization (LT) & -1.585 & 0.227 & -0.969 & -6.984 & 0.000 \\
\hline
\end{tabular}

Dependent Variable: KBBLM.

The regression coefficient with tcount D3TK 0.2641 .9720 .050 pvalue pvalue values $<5 \%$, then Ho is rejected it means with 95\% confidence level, if other factors held constant, D3TK positive and significant effect on the KBBLM

Value coefficient regression Business Type (JU) with options (Pt), (Pk), (TP), (H) and (OF) is (TP) -0,517dengan tcount -2.42 pvalue value 0.015 ; (H) 0483 with a value of 0,001 tcount 3,261 pvalue value; $(\mathrm{OF}) 0925$ with a value of 0,001 tcount 3.983 pvalue value; pvalue $<5 \%$, then Ho is rejected it means with $95 \%$ confidence level, if other factors held constant, JU with selection $(\mathrm{H})$ and $(\mathrm{OF})$ positive and significant impact on KBBLM. While the value of regression coefficient selection JU (TP) and no significant negative effect on KBBLM regression coefficient Dependent (Tg) with tcount $-0.72-2.1850 .030$ pvalue pvalue value $<5 \%$, then Ho is rejected it means with $95 \%$ confidence level, if other factors held constant, Tg significant negative effect on KBBLM.

Table 8. Regression coefficients values and testing results independent variables to KBBLM

\begin{tabular}{|c|c|c|c|c|c|c|}
\hline \multirow{2}{*}{\multicolumn{2}{|c|}{ Model }} & \multicolumn{2}{|c|}{$\begin{array}{l}\text { Unstandardized } \\
\text { Coefficients }\end{array}$} & \multirow{2}{*}{$\begin{array}{l}\text { Standardized } \\
\text { Coefficients } \\
\text { Beta } \\
\end{array}$} & \multirow[b]{2}{*}{$\mathrm{T}$} & \multirow[b]{2}{*}{ Sig. } \\
\hline & & $\mathrm{B}$ & Std. Error & & & \\
\hline \multirow[t]{8}{*}{1} & (Constant) & 0.187 & 0.069 & & 2.702 & .008 \\
\hline & $\mathrm{X}_{1}$ BLM Capital (BC) & 0.011 & 0.009 & 0.047 & 1.271 & 0.205 \\
\hline & $\mathrm{X}_{7}$ Type of Business (D4JU) & & & & & \\
\hline & Plantation (Pk) & 0.036 & 0.028 & 0.068 & 1.279 & 0.202 \\
\hline & Crops (TP) & -0.043 & 0.035 & -0.122 & -1.219 & 0.224 \\
\hline & Horticulture (H) & 0.118 & 0.025 & 0.333 & 4.766 & $0.000^{*}$ \\
\hline & Off Farm (OF) & 0.214 & 0.039 & 0.510 & 5.493 & $0.000 *$ \\
\hline & $\mathrm{X}_{12}$ Farmer Organization (LT) & -0.296 & 0.038 & -0.917 & -7.772 & $0.000 *$ \\
\hline
\end{tabular}


Value koefisiesn regression Business Type (JU) with options (Pt), (Pk), (TP), (H) and (OF) is $(\mathrm{H}) 0,118$ with highest of value tcount 4,766 value pvalue 0,000 ; (OF) 0214 with a value of 0,000 tcount 5,493 pvalue value; pvalue $<5 \%$, then Ho is rejected it means with $95 \%$ confidence level, if other factors held constant, JU with selection (H), (OF) positive and significant impact on KBBLM. LT regression coefficient value -0.296 to -7.772 tcount pvalue 0000 pvalue values $<5 \%$, then Ho is rejected it means with $95 \%$ confidence level, if other factors held constant, LT significant negative effect on the KBBLM.

\section{Conscluison}

- Capital Factors that taste of BLM, the Institute of Business and Tani significant effect on the success of the implementation of the BLM program in Ogan Ilir seen with the revolving fund, where there are $41 \%$ of those who carry out rolling the BLM program funds up to five (5) times. This is consistent with the goals and objectives of the BLM program where the funds should be used so that the continuity of the rolling program of economic development for the community to prosperity of rural communities can be achieved also the welfare of rural communities can be achieved.

- Statistical analysis showed that the independent variables have a strong relationship to the dependent variable, where the value of the coefficient of determination (Adjusted $\mathrm{R}^{2}$ ) of 0.762 . the Revenue Percentage Improvement BLM / Main Revenue (P3 / PU and amounted to 0.828 against the percentage increase farmers' income means that the model can explain the variance of data $76.2 \%$ of the success of the Programme BLM

- Simultaneously (F-test) Capitalvariable, Business Type, Farmers Institutions real and significant effect on the success of the BLM program. The results of the $t$ test (partially) Type of Business (Horticulture and Off Farm), has a positive and significant impact on the success of the BLM program. While the variable capital, and the Institute of farmers, a significant negative effect on KBBLM Program.

\section{Acknowledgements}

That the utilization of independent direct grants (BLM) can be accomplished in accordance with the provisions that must be revolving fund, it is recommended that the selection of the right type of business is Off Horticulture Farm because it can generate profit registered a daily / weekly / monthly and can be implemented in a narrow area. Need to be given guidance and assistance to the public about the business opportunities that can be developed more widely in the era of free competition to further streamline the role of the farmer.

\section{References}

Anantanyu, S. (2009). Participation of Farmers in Improving Institutional Capacity of Farmers Group (Case in Central Java Province). Dissertation at the Bogor Agricultural Institute.

Anantanyu, S. (2011). Farmer Institution: The Role and Strategy of Capacity Development. Journal, SEPA, 7(2), 102-109.

Friedmann, J. (1992). Empowerment the Political of Alternative Development. Cambridge, Massachusetts: Blackwell Publishers, Three Cambridge Center.

Kirdar, U., \& Leonard, S. (2001). People: From Impoverishment to Empowerment.

Kurniawati, E. (2013). Factors Affecting the Success of Rural Agribusiness Development Program (PUAP) Based on Regionalities in Magetan Regency. UGM City and Regional Planning Studies Program.

Lumintang, F. M. (2013). Analysis of Rice Farmers' Income in Teep Village, Lamongan Timur District. Faculty of Economics and Business, Department of Development Economics. Sam Ratulangi University of Manado. Journal of EMBA, 1(3), 991-998.

Singh, I., Squire, L., \& Strauss, J. (1986). The Basic Model: Theory, Empirical Result and Policy Conclusions. Agricultural Household Models: Extensions, Applications and Policy. Word Bank, The Johns Hopkins University Press., Baltimore.

Soekartawi. (2003). Agribusiness Theory and Its Application. Jakarta: PT. Raja Grafindo Persada.

Soekartawi. (2005). Agroindustry in Socio-Economic Perspective. Jakarta: PT Raja Grafindo Persada.

Sugiyono. (2010). Qualitative Quantitative Research Methods and R \& D, Alfabeta Bandung

Sujarno (2008). Analysis of Factors Affecting Fisherman's Income in Langkat District, 2008 USU Repository.

Sumardjo. (2010). Revitalization of Social Extension Role in the Implementation of Social Welfare. Paper presented by Congress of Social Extension Counselor Functional Officer Social Building Officer, Jakarta. 
Todaro, M. P., \& Smith, S. C. (1993). Economic Development.

\section{Copyrights}

Copyright for this article is retained by the author(s), with first publication rights granted to the journal.

This is an open-access article distributed under the terms and conditions of the Creative Commons Attribution license (http://creativecommons.org/licenses/by/4.0/). 